\title{
ASSOCIATION OF SOCIODEMOGRAFIC FACTORS AND SLEEP QUALITY IN BRAZILIAN UNIVERSITY STUDENTS ${ }^{1}$
}

\author{
Márcio Flávio Moura de Araújo², Adman Câmara Soares Lima33, Thiago Moura de Araújo4, Vivian Saraiva \\ Veras $^{5}$, Maria Lúcia Zanetti ${ }^{6}$, Marta Maria Coelho Damasceno ${ }^{7}$
}

\begin{abstract}
${ }^{1}$ Article selected from the thesis - Sleep quality among university students and their interaction with the metabolic syndrome and health indicators, presented to the Post-Graduate Program in Nursing of the Federal University of Ceará in 2012. Research Funded by CNPq throughout the Universal Bidding Announcement MCT/CNPq 14/2009, Case n. 474902/2009-9.

2 Ph.D. in Nursing. Associate Professor of the Nursing Department at the Universidade da Integração Internacional da Lusofonia Afro-Brasileira (UNILAB). Ceará, Brazil. Email: marciofma@yahoo.com.br

${ }^{3}$ Master in Nursing. Professor, Faculty of Education and Culture of Ceará. Ceará, Brazil. Email: adminhacs@hotmail.com

${ }^{4}$ Ph.D. in Nursing. Associate Professor of the Nursing Department at the Universidade da Integração Internacional da Lusofonia Afro-Brasileira (UNILAB). Ceará, Brazil. Email: thiagomouraenf@yahoo.com.br

${ }^{5}$ Ph.D. Student of the Post-Graduate Program of the School of Nursing of Ribeirão Preto, University of São Paulo (EERP-USP). São Paulo, Brazil. Email: vivianveras@hotmail.com

${ }^{6}$ Ph.D. in Nursing. Associate Professor of Nursing at EERP-USP. CNPq Researcher, São Paulo, Brasil. E-mail: zanetti@eerp. usp.br

${ }^{7}$ Ph.D. in Nursing. Professor of the Nursing Department and the Post-Graduate Nursing Program at the Federal University of Ceará (UFC). CNPq Researcher. Ceará, Brasil. E-mail: martadamasceno@terra.com.br
\end{abstract}

\begin{abstract}
The aim of this study was to analyze relationship between sociodemographic factors and poor sleep quality in Brazilian university students. Cross-sectional study, surveyed 701 students in Fortaleza, Ceará, Brazil. We applied a questionnairre with sociodemographic questions and Pittsburgh Sleep Quality Index. We did not identify associations and/or statistically significant linear trends between sleep quality and sociodemographic analyzed factors. However, the analysis found that the relative risk in college aged $\geq 31$ years, in those who lived alone and with relatives (other than parents) there is greater vulnerability to poor sleep quality.

DESCRIPTORS: Sleep. Sleep disorders. Students.
\end{abstract}

\section{RELAÇÕES ENTRE FATORES SOCIODEMOGRÁFICOS E QUALIDADE DO SONO EM UNIVERSITÁRIOS BRASILEIROS}

RESUMO: O objetivo deste artigo foi analisar a relação entre fatores sociodemográficos e a má qualidade do sono de universitários brasileiros. Estudo transversal que entrevistou 701 alunos de Fortaleza, Brasil, em 2011. Foi aplicado um formulário com questões sociodemográficas e o Índice de Qualidade do Sono de Pittsburgh. Não identificamos associações e/ou tendências lineares estatisticamente significantes entre a qualidade do sono e os fatores sociodemográficos analisados. Todavia, na análise do risco relativo constatamos que nos universitários com idade $\geq 31$ anos, naqueles que moravam sozinhos e com parentes (diferentes dos pais) há maior vulnerabilidade em relação à má qualidade do sono.

DESCRITORES: Sono. Transtornos do sono. Estudantes.

\section{ASOCIACIÓN ENTRE FACTORES SOCIODEMOGRÁFICOS Y CALIDAD DEL SUEÑO EN ESTUDIANTES UNIVERSITARIOS DE BRASIL}

RESUMEN: El propósito de este trabajo fue identificar la asociación entre los factores sociodemográficos y de mala calidad del sueño en estudiantes universitarios brasileños. Estudio transversal entrevistó a 701 estudiantes de Fortaleza, Ceará, Brasil en 2011. Se aplicó un formulario con preguntas demográficas y el Índice de Calidad del Sueño de Pittsburgh. No identificamos asociaciones y/o tendencias lineales estadísticamente significativas entre la calidad del sueño y lós factores sociodemográficos analizados. No identificamos asociaciones y/o tendencias lineales estadísticamente significativas entre la calidad del sueño y lós factores sociodemográficos analizados. Sin embargo, el análisis encontro que el riesgo relativo de lós estudiantes universitarios con edad $\geq 31$ años, lós que vivian solos y familiares que no tienen mayor vulnerabilidad a mala calidad del sueño.

DESCRIPTORES: Sueño. Transtornos del sueño. Estudiantes. 


\section{INTRODUCTION}

Biological clocks keep close relation to several human physiological variables such as blood pressure, immune system, blood coagulation, and gastric, endocrine and renal functions, as well as sleep. However, individual characteristics such as role in the family, response to stress and lifestyle can influence sleep hygiene. Some authors have shown that some sociodemographic variables may influence even chronotypes of the subjects. Besides morningness and eveningness, sleep hours can suffer local influences. Indirectly, sociodemographic variables may also be related to circadian rhythm, poor sleep quality, smoking, alcohol and caffeine consumption and some minor mental disorders. ${ }^{1-2}$

The sleeping habits result from a complex interaction of sociodemographic, behavioral, psychological and health factors. People with short or long sleep duration have distinct sociodemographic characteristics, life style and co morbidities from those with adequate sleep duration (7-8hours). ${ }^{3-4}$

Previous studies correlated sleep durations to sociodemographic variables among adults, middle-aged and old people however, those investigations have not evaluated the quality of sleep. Moreover, they analyzied multiple variables simultaneously, what has obfuscated the comprehension the role of each sociodemographic variable in sleep quality. ${ }^{3-7}$ Thereby, researches analyzing the correlation between sociodemographic factors and sleeping habits are important to increase comprehension of this relation in order to improve human health promotion as well as chronic diseases prevention programs elaboration. ${ }^{3-5}$

Nowadays, poor sleep quality among university students is a public health problem all around the world. This is consequence of In the last decades, the growing access to new technologies has changed university students' cultural habits and life style worldwide. This fact, has contributed to develop sleep disorders in this population, specially due to irregular sleeping schedule, long naps during the day, alcohol consumption before sleeping and the habit of studying lying in the bed $^{8-10}$

As far as we are concerned, there are no researches associating the quality of sleep among university students with sociodemographic variables. In addition, in Brazil, there are few studies published on the sleep of university students. Moreover, they have used reduced samples and none of them has established associations to sociodemographic variables. ${ }^{1,11-13}$ Thereby, this article aims to identify the associations between sociodemographic factors and poor sleep quality among Brazilian university students.

\section{METHOD}

\section{Design and population}

Cross-sectional study during February to June 2011 at the Federal University of Ceará, Fortaleza, Ceará, Brazil. The target population was undergraduate students, of both sexes, duly enrolled in this university campuses in the city of Fortaleza-CE. In this period, the estimated university population was 17,228 students, divided into six major areas of knowledge: humanities, sciences, agricultural sciences, health sciences, technological sciences, and sciences.

We calculated a simple random sample without replacement, using a formula to infinite populations. We adopted a rate of $50 \%(\mathrm{P}=\mathrm{Q}=$ $50 \%$ and $50 \%$ ) considering this value provides a maximum sample size, when set the significance level $(\alpha=0.05)$ and the relative sampling error of $8 \%$ (error absolute $=4 \%$ ). The sample resulted in 600 subjects. We estimated a rate of $10 \%$ for replacement questionnaires with wrong answers and/or incomplete and refusals. The final size of the sample totaled 701 students.

\section{Measurements}

The students answered a questionnaire containing five sections. The section used in this study refers to sociodemographics and sleep quality data.

Sleep quality was assessed based on a validated version, translated and adapted to Brazilian pattern of Pittsburgh Sleep Quality Index (PSQI). It consists of ten questions, with a maximum score of 21 points, which include seven components related to the quality of sleep within past month. The students with score above five points were classified as poor sleepers. ${ }^{14}$ The demographic characteristics were sex, age, color, monthly income, economic class, the person who the student lives with, marital status and employment. 


\section{Data collection}

Occurred from February to June the year 2011. Three nurses were responsible for data collection and underwent a six-hour training to become familiar with the instruments and ensure the reliability of data collected. Some college coordinators refused research authorization. Thereby, two undergraduate courses were selected by convenience from each knowledge area. Respondents studied different current year. They were invited to participate in the survey in classroom, after the explanation of the methods and goals of the study. Students answered two questionnaires, sociodemographics and other referent to sleep quality.

\section{Data analysis}

Inicially, data were entered in an Excel spreadsheet, and after typing were exported to statistical software STATA version 8.0. Data processing consisted in validating the internal consistency, calculation of descriptive measures (mean, standard deviation and median) and absolute and relative frequencies.

The differences between the sociodemographic and PSQI proportions were tested using the chi-square and Fisher exact's test. Proportional trends between the ordinal variables and PSQI were tested using the chi-square test for linear trend. Kruskal-Wallis test was used to compare differences in PSQI scores for knowledge area.

Prevalence of the PSQI was used as a measure of frequency and prevalence ratio (PR) as measure of association (95\%, confidence interval [IC]) depending on the estimated relative risk (RR) of Poisson robust regression. Poisson robust regression was used due to high prevalence of poor sleep quality found in population $(95.3 \%) .{ }^{15}$ In all analyzes, we adopted the statistical significance level of $5 \%(p \leq 0.05)$.

\section{Ethical aspects}

This research was approved by the Ethics Committee on Human Research of Health Sciences Center, Federal University of Ceará, protocol n. 208/2010.

\section{RESULTS}

The studied population comprises 701 university students from six academic areas, distributed in 24 graduation courses. Most participants were females $(62.7 \%)$, and the sample's average age was 21.5 years old ( $\mathrm{DP} \pm 4.5$ years). The age variable has shown an asymmetric distribution to the right (Kolmogorov Sminorv with $\mathrm{p}<0.001$ ).

Regarding to their races, the university students have declared themselves: brown (50.5\%), white $(36 \%)$, black ( $8 \%$ ) and pale $(5.5 \%)$. On the academic area item, the participants were distributed as follows: Humanities (20.4\%), Sciences (18.5\%), Exact Sciences (16.5\%), Technology (16\%), Health Sciences (15\%) and Agricultural Sciences (13.6\%). There was a predominance of students who were studying the first $(19.5 \%)$ and third $(20.8 \%)$ year.

Almost all participants were single (93\%), lived with their parents $(71.2 \%)$, and just studing for living $(65.2 \%)$. Most of them were from socioeconomic classes C (39.6\%) and B (39.7\%). These students had a familiar monthly income of U\$ 1.705 dollars (DP \pm 200$)$. It must be pointed out that $15 \%$ of the participants did not inform their monthly income value, and this variable presented an asymmetric distribution to the right (Kolmogorov Sminorv with $\mathrm{p}<0.001$ ).

In the analyzed sample, there was a $95.3 \%$ prevalence of poor sleep quality, what gives to the studied event a common outcome. It could be verified that the obtained association measures were similar regarding to sociodemographic characteristics and outcomes in both groups.

Table 1 - Sociodemographic characteristics of university students association to sleep quality ( $\mathrm{n}=701)$. Fortaleza, Brazil, 2011.

\begin{tabular}{lcccc}
\hline \multicolumn{1}{c}{$\begin{array}{c}\text { Sociodemographic } \\
\text { characteristics }\end{array}$} & Total $\mathbf{n ~ ( \% )}$ & Good $\mathbf{n ~ ( \% ) ~}$ & Poor n (\%) & $\boldsymbol{p}$ value \\
\hline Gender & & & \\
Male & $262(37.3)$ & $10(30.3)$ & $252(37.7)$ & $0.390^{*}$ \\
Female & $439(62.7)$ & $23(69.7)$ & $416(62.2)$ & \\
Age group & & &
\end{tabular}




\begin{tabular}{|c|c|c|c|c|}
\hline \multirow{2}{*}{$\begin{array}{c}\text { Sociodemographic } \\
\text { characteristics }\end{array}$} & \multicolumn{4}{|c|}{ Quality sleep } \\
\hline & Total n (\%) & Good n (\%) & Poor n (\%) & $p$ value \\
\hline 16 to 20 & $250(42)$ & $16(48.4)$ & $234(50.3)$ & $0.87 \dagger$ \\
\hline 21 to 25 & $283(47.5)$ & $16(48.4)$ & $267(40.2)$ & \\
\hline 26 to 30 & $42(7)$ & $1(3.0)$ & $41(6.1)$ & \\
\hline$\geq 31$ & $21(3.5)$ & & $21(3.1)$ & \\
\hline \multicolumn{5}{|l|}{ Marital status } \\
\hline Married/wedded & $42(6)$ & $1(3.0)$ & $41(6.1)$ & \\
\hline Single & $648(93)$ & 32 (96.9) & 616 (92.7) & \\
\hline Widower & $2(0.2)$ & & $2(0.3)$ & \\
\hline Divorced & $5(0.8)$ & & $5(0.7)$ & \\
\hline \multicolumn{5}{|l|}{ Race } \\
\hline White & $246(36)$ & $9(29.0)$ & $237(36.4)$ & \\
\hline Black & $53(8)$ & $4(12.9)$ & $49(7.5)$ & \\
\hline Brown & $345(50.5)$ & $17(54.8)$ & $328(50.3)$ & \\
\hline Pale & $38(5.5)$ & $1(3.2)$ & $37(5.9)$ & \\
\hline \multicolumn{5}{|l|}{ Socioeconomic class } \\
\hline$A$ & 74 & $1(3.0)$ & $73(10.9)$ & $0.29 \dagger$ \\
\hline B & 277 & $11(33.3)$ & $266(40)$ & \\
\hline C & 277 & $16(48.4)$ & $261(39.2)$ & \\
\hline $\mathrm{D}$ and $\mathrm{E}$ & 70 & $5(15.2)$ & $65(9.7)$ & \\
\hline \multicolumn{5}{|l|}{ Family monthly income } \\
\hline$<$ U\$ 290 & $24(4)$ & $2(7.1)$ & $22(3.8)$ & $0.93 \dagger$ \\
\hline U\$ 290-870 & 198(33.2) & $5(17.8)$ & $193(33.9)$ & \\
\hline U\$ 1.450-1.160 & $140(23.6)$ & $9(32.1)$ & $131(23)$ & \\
\hline > U\$ 1.160 & 234(39.2) & $12(42.8)$ & $222(39)$ & \\
\hline \multicolumn{5}{|l|}{ Employment situation } \\
\hline Only study & $454(65.2)$ & $20(62.5)$ & $434(65.3)$ & $0.436^{*}$ \\
\hline Study and work & $242(34.8)$ & $12(15.0)$ & $230(34.5)$ & \\
\hline \multicolumn{5}{|l|}{ Live with } \\
\hline Mother and/or father & $494(71.2)$ & $27(81.8)$ & $467(70.6)$ & \\
\hline Alone & $20(3)$ & & $20(3.0)$ & \\
\hline Spouse & $35(5)$ & $1(3.0)$ & $34(5.1)$ & \\
\hline Other Relatives & $118(17)$ & $3(9.0)$ & $115(17.4)$ & \\
\hline Friends & $27(3.8)$ & $2(6.0)$ & $25(3.7)$ & \\
\hline
\end{tabular}

Note: *Fischer's Chi-squared Test; †Tendência Linear Chi-squared Test.

The proportion for poor and good sleepers was higher among females students $(\mathrm{p}=0.390)$. In both groups, there was a predominance of single undergraduates $(p=0.820)$, who lived with their parents, it had pale skin $(\mathrm{p}=0.576)$ and that only studied for a living $(\mathrm{p}=0.436)$. Most poor sleepers were 16 to $20(50.3 \%)$ or 21 to 25 years old $(40.2 \%)$ $(\mathrm{p}=0.87)$, they also be longed to socioeconomic class B $(40 \%)(p=0.29)$. However, in none of these associations there were statistically significant differences between good and poor sleepers (Table 1).

Most poor sleepers undergraduates (39\%) had a monthly income of U\$ 1.160 dollars or more $(p=0.93)$ (Table 1). Regarding to academic area, there was equivalence on the prevalence of poor sleepers: 20\% (Humanities), 18.7\% (Sciences), 16.5\% (Exacts Sciences), 16.3\% (Technology) and $13.8 \%$ (Agricultural Sciences).

No statistically significant differences ocurred between the mean of PSQI score by knowledge area $(p=0.706)$. The mean and median PSQI score values in almost all areas of knowledge was approximately 9 (DP $\approx 1.9$ to 2.5 ), except for the human health areas and when media was 10 points. Human and health sciences areas showed greater variations. 
It was found percentages higher than $90 \%$ of poor sleep quality among both freshmen and veterans. From these, most poor sleeper participants $(56.8 \%)$ were freshmen (ones studying the college first or second year). All the evaluated undergraduates from the last terms (fourth to sixth years) were classified as poor sleepers. Furthermore, there was not a significant statistically correlation between academic term and sleep quality $(\mathrm{p}=0.137)$ (Table 2).

Table 2 - Distribution of PSQI indicator between novice and veteran students stratified by knowlegde area. Fortaleza, Brazil, 2011

\begin{tabular}{|c|c|c|c|c|c|c|c|c|c|c|c|c|}
\hline \multirow[t]{2}{*}{ Index } & \multicolumn{6}{|c|}{$\begin{array}{c}\text { Novice } \\
\text { Knowlegde area* }\end{array}$} & \multicolumn{6}{|c|}{$\begin{array}{c}\text { Veteran } \\
\text { Knowlegde area }\end{array}$} \\
\hline & $\begin{array}{c}1 \\
\text { n (\%) }\end{array}$ & $\begin{array}{c}2 \\
\text { n (\%) }\end{array}$ & $\begin{array}{c}3 \\
\text { n (\%) }\end{array}$ & $\begin{array}{c}4 \\
n(\%)\end{array}$ & $\begin{array}{c}5 \\
\text { n (\%) }\end{array}$ & $\begin{array}{c}6 \\
n(\%)\end{array}$ & $\begin{array}{c}1 \\
n(\%)\end{array}$ & $\begin{array}{c}2 \\
n(\%)\end{array}$ & $\begin{array}{c}3 \\
n(\%)\end{array}$ & $\begin{array}{c}4 \\
n(\%)\end{array}$ & $\begin{array}{c}5 \\
n(\%)\end{array}$ & $\begin{array}{c}6 \\
n(\%)\end{array}$ \\
\hline PSQI & & & & & & & & & & & & \\
\hline Good sleepers & $7(8,8)$ & $4(5,9)$ & $3(4,4)$ & $4(7,4)$ & $3(3,8)$ & $2(5,5)$ & $3(4,4)$ & $2(4)$ & & $2(4,3)$ & $2(6,6)$ & $1(1,7)$ \\
\hline Poor sleepers & $\begin{array}{r}69 \\
(91,2)\end{array}$ & $\begin{array}{r}63 \\
(95,1)\end{array}$ & $\begin{array}{r}65 \\
(95,6)\end{array}$ & $\begin{array}{r}50 \\
(92,6)\end{array}$ & $\begin{array}{r}97 \\
(92,2)\end{array}$ & $\begin{array}{r}34 \\
(94,5)\end{array}$ & $\begin{array}{r}64 \\
(95,6)\end{array}$ & $\begin{array}{r}47 \\
(96)\end{array}$ & $\begin{array}{r}44 \\
(100)\end{array}$ & $\begin{array}{r}44 \\
(95,7)\end{array}$ & $\begin{array}{r}28 \\
(93,4)\end{array}$ & $\begin{array}{r}58 \\
(98,3)\end{array}$ \\
\hline
\end{tabular}

* Note - 1: Humanities 2; Exacts Sciences 3; Technology 4; Health Sciences 5; Sciences 6; Agricultural Sciences.

The results showed a positive and statistically significant association between age and poor sleep quality among the researched subjects. Among undergraduates aged $\geq 31$ years, the chan- ces of poor sleep quality occurrence was 1.05 times higher (IC 95\% 1.02-1.07) than among students aged 16 to 20 years old $(\mathrm{p}<0.001)$ (Table 3$)$.

Table 3 - Association between the PSQI indicator and the university students' sociodemographic factors (n=701). Fortaleza, Brazil, 2011

\begin{tabular}{|c|c|c|c|}
\hline Sociodemographic factors & $\begin{array}{c}\text { Poor sleep group } \\
n(\%)\end{array}$ & $\mathbf{P R}^{*}$ & IC $95 \% *$ \\
\hline \multicolumn{4}{|l|}{ Gender } \\
\hline Male & $252(96.2)$ & 1.00 & -- \\
\hline Female & 416 (94.8) & 0.98 & $0.95-1.02$ \\
\hline \multicolumn{4}{|l|}{ Age group (years) } \\
\hline 16 to 20 & $334(95.4)$ & 1.00 & -- \\
\hline 21 to 25 & $267(94.4)$ & 1.00 & $0.96-1.03$ \\
\hline 26 to 30 & $41(97.6)$ & 1.02 & $0.97-1.08$ \\
\hline$\geq 31$ & $21(100.0)$ & 1.05 & $1.02-1.07$ \\
\hline \multicolumn{4}{|l|}{ Marital status } \\
\hline Married /unmarried cohabitation & $41(97.6)$ & 1.00 & -- \\
\hline Single & $616(95.1)$ & 0.98 & $0.91-1.04$ \\
\hline Widower/Divorced & $7(100.0)$ & 1.02 & $0.99-1.07$ \\
\hline \multicolumn{4}{|l|}{ Race } \\
\hline White & $237(96.3)$ & 1.00 & -- \\
\hline Black + Brown & $365(95.3)$ & 0.99 & $0.96-1.02$ \\
\hline Pale & $49(92.4)$ & 0.96 & $0.88-1.04$ \\
\hline \multicolumn{4}{|l|}{ Socioeconomic class classification } \\
\hline A & $73(98.6)$ & 1.00 & -- \\
\hline B & 266 (92.9) & 0.97 & $0.94-1.01$ \\
\hline C & $261(96.0)$ & 0.96 & $0.92-1.00$ \\
\hline $\mathrm{D}$ and $\mathrm{E}$ & 65 (94.2) & 0.94 & $0.87-1.01$ \\
\hline \multicolumn{4}{|l|}{$\begin{array}{l}\text { Family monthly income } \\
\text { (American dollars) }\end{array}$} \\
\hline$<$ U\$ 290 & $22(91.7)$ & 0.96 & $0.85-1.09$ \\
\hline U\$ 290-870 & $193(97.5)$ & 1.03 & $1.00-1.07$ \\
\hline
\end{tabular}




\begin{tabular}{lccc}
\hline \multicolumn{1}{c}{ Sociodemographic factors } & $\begin{array}{c}\text { Poor sleep group } \\
\mathbf{n}(\%)\end{array}$ & PR $^{*}$ & IC 95\%* \\
\hline U\$ 1.450-1.160 & $131(93.6)$ & 0.99 & $0.94-1.04$ \\
> U 1.160 & $222(94.9)$ & 1.00 & -- \\
Working situation & & & -- \\
Only study & $434(95.6)$ & 1.00 & $0.96-1.04$ \\
Study and work informally & $230(93.6)$ & 1.00 & -- \\
Leave with & & & $\mathbf{1 . 0 3 - 1 . 0 8}$ \\
Mother and/or father & $467(94.5)$ & 1.00 & $0.95-1.10$ \\
Alone & $\mathbf{2 0 ( 1 0 0 . 0 )}$ & $\mathbf{1 . 0 5}$ & $\mathbf{1 . 0 0 - 1 . 0 7}$ \\
Spouse & $34(97.1)$ & 1.02 & $0.88-1.09$ \\
Parents & $\mathbf{1 1 5 ( 9 7 . 5 )}$ & $\mathbf{1 . 0 3}$ & \\
Friends & $25(92.6)$ & 0.98 & \\
\hline
\end{tabular}

*Note - Prevalence Ratio: estimated based on robust Poisson regression adjusted by age and gender.

It was evidenced a positive and statistically significant association between living alone or with relatives and poor sleep quality. In those cases, the chance of an undergraduate who lives alone or with parents to present poor sleep quality was $1.05(p<0.001)$ and $1.03(p=0.020)$ higher, respectively, than ones of those students who live with their spouse, friends and other relatives. The undergraduates from socioeconomic class $\mathrm{C}$ and those with monthly income between U\$ 290 and 870 dollars also showed greater chances of poor sleep quality occurrence (Table 3 ).

\section{DISCUSSION}

In this research, it was not verified statistically significant association between gender and sleep quality among university students. Most studies addressing this issue have gotten this same conclusion..$^{8-13,16-20}$ However, researches that have found significant statistical divergences have pointed female undergraduates as being the most affected by sleeping problems. ${ }^{21-26}$

Women between 18 and 24 years go to bed and wake up earlier than men, but both genders showed equivalent amounts of total sleeping time, number of awakenings during the night and day naps. Other non-biological factors, as role in the family, response to stress and life style may also be involved with gender differences. For example, it was reported that childcare and partner's sexual disorders are the two main causes of young women nocturnal awakenings. ${ }^{27}$

This research identified greater vulnerability to poor sleep quality between economic class C college students and those with monthly income only 290-870 dollars. Epidemiological studies have found robust evidences that economic situation is a predictor for nocturnal sleep quality. The subjects who have worked on low income activities are the most inclined ones to develop problems on latency and sleep duration, awakening and diurnal somnolence than those who work on better status occupations. ${ }^{5,27-32}$

Currently, there is a massive diffusion of technologies such as social networks, mobile devices with internet access and many applications that keeping their attention at times for the rest, and consequently hinder the latency and sleep efficiency. Technological resources are even more accessible to young people of higher socioeconomic status. The labor demand for these young people, especially those with less favorable socioeconomic conditions, lead great effort in their academic activities in order to maintain or improve their pattern current life. Inevitably, this might also be involved in the genesis of sleep problems.

This divergence occurred due to these studies have been carried out more than five years ago. At that time, the massive spread of technology, as social networks, mobile phones with internet connection and applications, had not happened yet. These technologies may catch young people's attention in moments they should be resting, what, consequently, makes latency and sleep efficiency more difficult.

Despite of the increase on technological resources offer they are still more available for the young people on a good socioeconomic situation. Furthermore, current working competition demands great effort on academic activities, even for those in a good socioeconomic situation, in order to keep or improve one's pattern of living. This might also be inevitably related to the sleeping problems origin.

This research has not found relationship between academic area of knowledge and quality 
of sleep. In literature, there is not an agreement on this association, however, earlier studies carried out in Portugal, Lithuania, China, Thailand and South Korea have verified that undergraduates from the Humanities and Health Sciences are the most stricken to problems related to sleep quality and quantity reduction. ${ }^{9,4,33-35}$

In this cases, the preponderant variable is not the academic area the undergraduate studies, but his/her life style, which increases his/her vulnerability to sleep disorders. However, even a fulltime student, who faces many academic exigencies, is able to study efficiently as well as have some pleasure and maintains his/her social life in such a way that his/her sleep quality is not impaired.

This research identified that students who live alone or with relatives (other than parents) have more chances to be poor sleepers compared to those who live with a partner(a), friends and their parents.

Regarding those who live alone, this is not surprising, because the sudden freedom experienced by these young people when they go to College can cause a situation of sleep deprivation and serious health problems. They go through stressing situations as home maintenance, noise environments and bad accommodations, especially those who adopt free academic quarters. ${ }^{26,36}$ Living alone increases the sleep health vulnerability because one does not realize that suffers from problems as snoring, Restless Legs Syndrome or even Sleep Apnea. All these situations depend on external observation to be detected.

By the other hand, living with parents acts as a relaxing factor and good sleep preditor for these students. Regarding students who live with friends, there is also an improvement of sleep because they alternate schedules for study and leisure with friends. ${ }^{24}$

Generally speaking, universities can reduce these problems with some arrangements, such as: insalubrities reduction at the academic housings and sleep health services offer, which focus on prevention and treatment. This fact must be taken into account, mainly, at the great Universities, which routinely receive students from different places and even different countries.

This research has also investigated the statistically significant correlation between aging and poor sleeping quality. Researches on this issue did not present equal results, because some of them have identified similar and opposite results and some have not identified a statistically significant association this crossing. ${ }^{19,37-39}$ Moreover, the distance between ones biological and chronological ages makes this comparison difficult. ${ }^{40}$ So far, we have the following robust evidences for this association: as people get older there is a proportional reduction on the slow-wave sleep (which promotes a better restorative sleep) and an increase of the prevalence in insomnia and risk factors for Sleep Apnea and snoring. ${ }^{40-43}$

Based on this research results and the evidences pointed out by literature, changes detected in middle-aged and old people have not necessarily started at these ages. They are part of a sleep evolutionary process which may have started before the senescence. Therefore, it is fundamental to give attention to undergraduate's sleep because these young individuals may already present discrete sleep disorders that will get chronic over time and make several chronic health problems possible.

\section{CONCLUSION}

University students with good socioeconomic profile, who live alone or with their parents, and who are older than 31 years have more chances to present poor sleep quality. Undergraduates from Agricultural Sciences and Technology have shorter sleep duration than students from Sciences, Humanities, Health Sciences and Exact Sciences. Health professionals who work with school health at Universities should pay attention to sociodemographic characteristics which increase the undergraduates' vulnerability related to poor sleep quality. Based on research results, nurses may also develop health education considering this issue in student's context.

\section{REFERENCES}

1. Schneider MLM, Vasconcellos DC, Dantas G, Levandovski R, Caumo W, Allebrandt KV, et al. Morningness-eveningness, use of stimulants, and minor psychiatric disorders among undergraduate students. Int J Psychol. 2010 Feb; 46(1):18-23.

2. Nogueira AD, Riu TC, Hortensi JV, Cucurella NC. Cronobiologia. Porto Alegre (RS): Editora Livre; 2007.

3. Stranges S, Dorn JM, Shipley MJ, Kandala NB, Trevisan M, Miller MA, et al. Correlates of short and long sleep duration: a cross-cultural comparison between the United Kingdom and the United States. Am J Epidemiol. 2008 Dec; 168(2):1353-64.

4. Ryu SY, Kim KS, Han MA. Factors associated with sleep duration in Korean adults: results of a 2008 community health survey in Gwangju metropolitan city, Korea. J Korean Med Sci. 2011 Sep; 26(9):1124-31. 
5. Adams J. Socioeconomic position and sleep quantity in UK adults. J Epidemiol Community Health. 2006 Mar; 60(3):267-9.

6. Moore P, Adler N, Williams D, Jackson JS. Socioeconomic status and health: the role sleep. Psychosom Med. 2002 Mar-Apr; 64(2):337-44.

7. Friedman EM. Sleep quality, social well-being, gender, and inflammation: an integrative analysis in a national sample. Ann N Y Acad Sci. 2011 Aug; 1231:23-34

8. Kang JH, Chen SC. Effects of an irregular bedtime Schedule on sleep quality, daytime sleepiness, and fatigue among university students in Taiwan. BMC Public Health. 2009 Jul; 19:248.

9. Ban DJ, Lee TJ. Sleep duration, subjective sleep disturbances and associated factors among university students in Korea. J Korean Med Sci. 2001 Aug; 16(1):475-80.

10. Herrera AR, Silva RP, Gomez MV, Hernández GR, Nóbrega MPSS, Mitchell C, et al. Policonsumo simultáneo de drogas em estudiantes de facultades de ciencias de la salud/ciencias médicas en siete universidades de cinco países de América Latina y un país del Caribe: implicaciones de gênero, legales y sociales. Texto Contexto Enferm. 2012 Set; 21(n. esp)17-24.

11. Furlani R, Ceolim MF. Padrões de sono de estudantes ingressantes na graduação em enfermagem. Rev Bras Enferm. 2005 Mai-Jun; 58(3):320-4.

12. Mesquita G, Reimão R. Quality of sleep among university students: effects of nighttime computer and television use. Arq Neuropsiquiatr. 2010 Oct; 68(5):720-5.

13. Cardoso HC, Bueno FCC, Mata JC, Alves APR, Jochims I, Vaz Filho IHR, et al. Avaliação da qualidade do sono em estudantes de medicina. Rev Bras Educ Med. 2009 Jul-Sep; 33(3):349-55.

14. Bertolazi AN, Fagondes SC, Hoof L, Dartora EG, Miozzo IC, Barba ME, et al. Validation of the Brazilian portuguese version of the Pittsburgh sleep quality index. Sleep Med. 2011 Jan; 12(1):70-5.

15. Barros AJD, Hirakata VN. Alternatives for logistic regression in cross-sectional studies: an empirical comparison of models that directly estimate the prevalence ratio. BMC Med Res Methodol. 2003 Oct; 3:21.

16. Reid A, Baker F. Perceived sleep quality and sleepiness in South African university students. South African J Psychol. 2005 Jun; 38(2):287-303.

17. Lehnkering $\mathrm{H}$, Siegmund R. Influence of chronotype, season, and sex of subjective on sleep behavior of young adults. Chronobiol Int. 2007 Sep; 24(5):875-88.

18. Danda GJN, Ferreira GR, Azenha M, Bastos KFRSO. Padrão do ciclo sono-vigília e sonolência excessiva diurna em estudantes de medicina. J Bras Psiquiatr. 2005 Abr-Jun; 54(2)102-6.
19. Huen LL, Chan TWG, Yu WMM, Wing YK. Do medical students in Hong Kong have enough sleep? Sleep Biol Rhythms. 2007 Jul; 5(7):226-30.

20. Pallos H, Gergely V, Yamada N, Miyazaki S, Okawa $\mathrm{M}$. The quality of sleep and factors associated with poor sleep in Japanese graduate students. Sleep Biol Rhythms. 2007 Dec; 5(4):234-8.

21. Tsai LL, Li SP. Sleep education in college: a preliminary study. Percept Mot Skills. 2004 Dec; 99(3):837-48.

22. Kang, JK, Lim HD, Lee YM. Association between sleep quality and psychologic factors among university students in Korea. J Korean Acad Orofacial Pain Oral Med. 2008 Oct; 33(4):257-67.

23. Akhlagi AAK, Ghalebandi MF. Sleep quality and its correlation with general health in pre-university students of Karaj, Iran. IJPBS. 2009 Sep; 3(1):44-9.

24. Falavigna A, Bezerra MLS, Teles AR, Kleber FD, Velho MC, Steiner B. Sleep disorders among undergraduate students in Southern Brazil. Sleep Breath. 2010 Sep; 15(3):519-24.

25. Galambos NL, Howard AL, Maggs JL. Rise and fall of sleep quantity and quality with student experiences across the first year of university. J Res Adolesc. 2010 Jun; 21(2):342-9.

26. Kongsomboon K. Psychological problems and overweight in medical students compared to students from Faculty of Humanities, Srinakharinwirot University, Thailand. J Med Assoc Thai. 2010 Dec; 93(Suppl 2):106-13.

27. Kloss JD, Nash CO, Horsey SE, Taylor DJ. The delivery of behavioral sleep medicine to college students. J Adolesc Health. 2011 Jun; 48(6):553-61.

28. Hunt SM, Mcewen J, Mckenna SP. Social inequalities and perceived health. Eff Health Care. 1985 AugDec; 2(4):151-60.

29. Hyyppa MT, Kronholm E, Alanen, E. Quality of sleep during economic recession in Finland: a longitudinal cohort study. Soc Sci Med. 1997 Sep; 45(5):731-8.

30. Geroldi C, Frisoni GB, Rozzini R, De Leo, D, Trabucchi M. Principal lifetime occupation and sleep quality in the elderly. Gerontology. 1996 May; 42(3):163-9.

31. Hall M, Brombeger J, Matthews K. Socioeconomic status as a correlate of sleep in African-American and caucasian women. Ann N Y Acad Sci. 1999 Dec; 896:427-30.

32. Sekine M, Chandola T, Martikainnen P, Mcgeohegan D, Marmot M, Kagamimori S. Explaining social inequalities in health by sleep: the Japanese civil servants study. J Public Health. 2006 Nov; 28(1):63-70.

33. Friedman EM, Love GD, Rozenkrans MA, et al. Socioeconomic status predicts objective and subjective sleep quality in aging women. Psychosom Med. 2007 Aug; 68(7):682-91. 
34. Henriques APFCM. Caracterização do sono dos estudantes universitários do Instituto Superior Técnico [dissertação]. Lisboa (PT): Universidade de Lisboa. Programa de Pós-Graduação em Medicina do Sono; 2008.

35. Preišegolavičiūtė E, Leskauskas D, Adomaitienè D. Associations of quality of sleep with lifestyle factors and profile of studies among Lithuanian students. Medicina (Kaunas). 2010 Jul; 46(7):482-9.

36. Tsui YY, Wing YK. A study on the sleep patterns and problems of university business students in Hong Kong. J Am Coll Health. 2009 Sep-Oct; 58(2):167-76.

37. Beck R, Taylor C, Robbins M. Missing home: sociotropy and autonomy and their relationship to psychological distress and homesickness in college freshmen. Anxiety Stress Cop. 2003 Jun; 16(2):155-66.

38. Suen LK, Hon KL, Tam WW. Association between sleep behavior and sleep-related factors among university students in Hong Kong. Chronobiol Int. 2008 Sep; 25(5):760-75.

39. Tomfohr L, Pung MA, Edwards KM, Dimsdale JE. Racial differences in sleep architecture: The role of ethnic discrimination. Biol Psychol. 2012 Jan; 89(1):34-8.

40. Neruntarat C, Chantapant S. Prevalence of sleep apnea in HRH Princess Maha Chakri Srinthorn Medical Center Thailand. Sleep Breath. 2011 Dec; 15(4):641-8.

41. Tufik S. Medicina e biologia do sono. Barueri (SP): Manole; 2008.

42. Landolt HP, Dijk DJ, Achermann P, Borbély AA. Effect of age on the sleep EEG: slow-wave activity and spindle frequency activity in young and middleaged men. Brain Res. 1996 Nov; 738(2):205-12.

43. Bliwise DL. Principles and practice of sleep medicine. Philadelphia (US): Saunders; 2000. 